\title{
Inappropriate Practices in Physical Education: The Top Eight Repeat Offenders 體育教學常犯的錯諮
}

David BARNEY

Brigham Young University, U.S.A.

Keven PRUSAK

Brigham Young University, U.S.A.

Brad STRAND

North Dakota State University, U.S.A.

Robert CHRISTENSON

Oklahoma State University, U.S.A.

\begin{abstract}
The National Association of Sport and Physical Education (NASPE) have created three documents (elementary, middle school and high school) to guide physical educators in appropriate instructional practices (AIP) in physical education. The purpose of these documents is to aid physical educators in exposing their students to lessons and activities that will enable them to be successful in physical education classes and physical activity. Unfortunately, many students have been exposed to such activities as dodge ball, having captains picking teams in front of the whole class, and many others. This paper is a review of research dealing with appropriate instructional practices in physical education with a multitude of different populations. From these different populations, eight instructional practices have been repeatedly misidentified. These eight repeat offenders will be discussed.
\end{abstract}

Keywords: Physical Education, Appropriate Instructional Practices, Inappropriate Instructional Practices

\section{Introduction}

Consider the following conversation that occurred at a local supermarket between a middle school physical educator and a parent, whose son is a student in the physical educator's class. The parent says to the physical educator, "I loved physical education class when I was a young boy". The physical educator is happy to hear this; and asks the parent, "Why was your physical education experience so enjoyable?" The parent proceeds by saying, "I enjoyed participation in dodge ball. I remember the fun I had in throwing the ball and hitting classmates in certain parts of their body that caused pain or discomfort." And then in the same breath the parent continues, "when teams were created during classes I was often selected to serve as a team captain." As the parent discusses the merits of these instructional practices as he remembers them, the physical educator feels uncomfortable.

This parent has just described two inappropriate instructional practices in physical education, playing dodge ball and having captains pick teams. The National Association of Sport and Physical Education (NASPE) created three documents (one for elementary school (NASPE, 2009a), middle school (NASPE, 2009b), and high school (NASPE, 2009c) physical education) to guide physical educators in appropriate instructional practices (AIP). 
These documents "offer specific guidelines for recognizing and implementing developmentally appropriate practices in (elementary, middle school \& high school) physical education" (Barney \& Strand, 2008, p. 34).

The purpose of these documents is to aid physical educators in exposing students to AIP's in physical education, thus enabling students to be successful in physical activity throughout their lives (Barney, Strand \& Prusak, 2013). Each of these documents is organized into five sections: Learning Environment, Instructional Strategies, Curriculum, Assessment and Professionalism. Each of the five sections give specific appropriate and inappropriate practices found in the physical education setting.

\section{Theoretical Framework}

With continued study of the AIP documents, it becomes clear that the physical educator is the person who will implement these instructional practices during class lessons and activities. With the implementation of AIP in physical education there is a link that may facilitate a task/mastery class environment, thus motivating student learning.

Task-involved climates are highly associated with adaptive learning strategies and behaviors, such as selfreferenced learning, persistence in the activity, effort, good behavior and motivation (Duda, 1996). Conversely, egoinvolved class climates are associated with maladaptive learning strategies and behaviors, such as normative comparisons, task avoidance, deception and cheating, discounting, bad attitudes, amotivation and withdrawal (Ames \& Archer, 1988). Research has demonstrated that the teacher can create a task-oriented class climate that can override a students' ego oriented disposition (Prusak, Treasure, \& McGee, 1998).

The TARGET approach (Ames \& Archer, 1988) offers a structure for physical educators to create a taskoriented climate in the class. The ' $\mathrm{T}$ ' represents the Tasks students participate in class, e.g., assignments, homework, and design of tasks. The 'A' represents Authority of student participation in the instructional process. More specifically, students "buying in" to activities that may not necessarily be their favorite, but student's believe they are "worth it." The 'R' represents Recognition of student accomplishments. This can be in the form of positive praise or reinforcement, limiting peer comparisons and recognizing the value of and reward process outcomes not just the end product. The ' $G$ ' represents Grouping of students, e.g., students working with other students or groups of students. The 'E' represents Evaluation or assessment in class activities. And the ' $\mathrm{T}$ ' represents Time, the pacing of learning and management of the class (Ames, 1992). The AIP statements link to the achievement goal theory by providing instructional practices that can create a taskinvolved climate for students in physical education. Thus positively affecting a student's motivation.

\section{Overview of AIP Research}

What follows is a small sampling of research related to the AIP topics of learning environment, instructional strategies, curriculum, and assessment in physical education.

\section{Learning Environment}

Burak, Rosenthal, \& Richardson (2013) examined the experience, the attitudes, the beliefs, and the intentions of college physical education majors and non-physical education majors regarding the use of exercise as a form of behavior management or punishment. Results showed evidence of the pervasiveness of the practice of exercise as punishment as more than $91 \%$ of the participants indicated that their coaches/teachers had used exercise as a form of punishment or behavior management, and $43 \%$ reported that their physical education teachers had used exercise as punishment or behavior management. Disturbingly, many of the participants indicated that they would use exercise as punishment when they become teachers and/or coaches.

The fact that many future physical educators and coaches support the use of exercise as punishment, despite the negative effects it can have on students and athletes, and despite the opposition to the practice by national sport, health, and educational organizations, should give physical education teaching and coaching educators concern. The literature concludes that the influence physical educators and coaches could have over their students and athletes, and the effects that influence have on attitudes, may impact participation in physical activity throughout one's lifetime. 


\section{Instructional Strategies}

Pantanowitz, Lidor, Nemet, \& Eliakim (2011) examined the attitudes and compliance towards homework assignments in physical education among high school students in Israel. They surveyed 95 students in grades 11 and 12 along with their parents. Students were asked about their physical activity habits, and both students and the parents were asked how they perceived the provision of homework assignments in physical education. It was found that over $90 \%$ of the parents and more than half of the students supported homework assignments in physical education. Despite this support, very few (4\%) of the students complied with all homework assignments, and less than half complied with even some of the given assignments. With the low percentages of students that complied with their homework assignments, the researchers concluded that homework in physical education has the potential for increasing regular physical activity, thus improving fitness, and promoting a healthier lifestyle in high school students.

\section{Curriculum}

Scantling, Strand, Lackey, \& McAlesse (1995) studied the determinants of why high school students in the United States (Nebraska, Idaho and Utah), choose not to take elective physical education classes once they had completed their graduation requirements. From the 1,438 surveyed high school students it was found that a majority of students avoided taking elective physical education classes because there was little or no curricular time to take both elective physical education and additional college prep coursework. Further analysis of the data found that over $30 \%$ of the students indicated that physical educators provide the same curriculum over and over again, meaning little variety. The researchers suggested that physical educators need to be flexible or creative in the course offerings and that a variety of activities should be offered to encourage students to enroll in elective physical education classes.

\section{Assessment}

Bryan and Solmon (2007) examined motivational constructs to help identify strategies that can be used in physical education classes to promote engagement in physical activity. One aspect of the research dealt with physical educators assessing students' fitness and skill levels. The researchers suggested that physical educators should emphasize self-improvement rather then social comparison. Physical educators are responsible for creating an environment that challenges students to do their best, and does not leave them feeling like they have been eliminated because their fitness or skill levels are different from other students. Additionally, students must perceive that their physical education classes provide some form of autonomy. Providing choices in physical education is relatively easy to do and choices should be fixed so that the options are acceptable to the teacher and always safe for the students. When teachers can provide different, yet challenging, levels of fitness and skill levels, student assessment will provide a positive experience for students (Prusak, 2005).

\section{AIP Research}

Table 1 details a number of research studies that specifically address the AIP documents. These studies surveyed parents (Barney \& Pleban, 2010), elementary aged students (Barney \& Christenson, 2014), middle school students (Barney, Prusak \& Strand, 2013), high school students (Barney \& Strand, 2008), elementary education majors (Strand, Barney \& DeFries-Evans, 2008; Barney \& Strand, 2006), physical education teacher education majors (PETE) (Barney \& Christenson, 2013; Barney, Christenson \& Pleban, 2012; Barney, Christenson \& Pleban, in press), school administrators (Barney \& Prusak, in press), and K-12 physical educators (Strand \& Bender, 2011).

For all of the surveys in these studies, statements were drafted from the AIP documents and participants were asked to identify if they believed the instructional practice described in the statement was appropriate or inappropriate in physical education. In most instances the same statements were included in the surveys for the various groups. 
Table 1 Overview of Appropriate Instructional Practices Research.

\begin{tabular}{|c|c|c|c|}
\hline Author & Purpose of Study & Participants & Results \\
\hline $\begin{array}{l}\text { Barney \& Christenson } \\
\text { (2014) }\end{array}$ & $\begin{array}{l}\text { To investigate elementary- } \\
\text { aged students knowledge } \\
\text { of AIP in elementary PE }\end{array}$ & $\begin{array}{l}2479 \text { elementary aged } \\
\text { students from } 14 \text { schools } \\
\text { from the southern plains }\end{array}$ & $\begin{array}{l}\text { PE class should have 'winner and } \\
\text { losers' } \\
\text { Students should all do the same } \\
\text { fitness activities } \\
\text { Playing dodge ball is appropriate } \\
\text { Exercise as punishment } \\
\text { Captains pick teams in front of } \\
\text { the whole class } \\
\text { Student getting an award for } \\
\text { reaching a certain level of fitness } \\
\text { Boys against girls is appropriate } \\
\text { Students graded on dribbling a } \\
\text { basketball through cones } \\
\text { Play games with adult rules, } \\
\text { equipment and playing area }\end{array}$ \\
\hline $\begin{array}{l}\text { Barney \& Christenson } \\
\text { (2013) }\end{array}$ & $\begin{array}{l}\text { To gain knowledge what } \\
\text { PETE majors know about } \\
\text { AIP in elementary PE }\end{array}$ & $\begin{array}{l}313 \text { PETE majors from } \\
\text { seven universities in the } \\
\text { United States }\end{array}$ & $\begin{array}{l}\text { Curriculum should consist of large } \\
\text { groups and competitive team games } \\
\text { Fitness tests should administered } \\
\text { for the purpose of awarding } \\
\text { students fitness levels } \\
\text { Dress, attendance and effort should } \\
\text { be graded as an affective portion } \\
\text { of a students grade } \\
\text { Dodge ball is appropriate }\end{array}$ \\
\hline $\begin{array}{l}\text { Barney, Strand, Prusak } \\
\text { (2013) }\end{array}$ & $\begin{array}{l}\text { To investigate middle } \\
\text { grade (6-9) students } \\
\text { knowledge of AIP in } \\
\text { middle grade PE }\end{array}$ & $\begin{array}{l}868 \text { middle grade } \\
\text { students in the Midwest }\end{array}$ & $\begin{array}{l}\text { Teacher organizes large-sided games } \\
\text { Captains pick teams in front of } \\
\text { the whole class } \\
\text { Having homework in PE is } \\
\text { inappropriate } \\
\text { Students in PE should be graded } \\
\text { on dress and attendance in class }\end{array}$ \\
\hline
\end{tabular}




\begin{tabular}{|c|c|c|c|}
\hline $\begin{array}{l}\text { Barney \& Christenson } \\
(2012)\end{array}$ & $\begin{array}{l}\text { To gain knowledge of } \\
\text { PETE majors knowledge } \\
\text { regarding AIP }\end{array}$ & $\begin{array}{l}313 \text { PETE majors from } \\
\text { seven universities in the } \\
\text { United States }\end{array}$ & $\begin{array}{l}\text { Mass exercise with a group leader } \\
\text { Captains pick teams in front of the } \\
\text { whole class } \\
\text { Student grades based on dress and } \\
\text { attendance } \\
\text { General feedback is all that is } \\
\text { needed to help with student learning }\end{array}$ \\
\hline Strand \& Bender (2011) & $\begin{array}{l}\text { Gain insights from current } \\
\text { PE teachers about their } \\
\text { knowledge of AIP strategies }\end{array}$ & 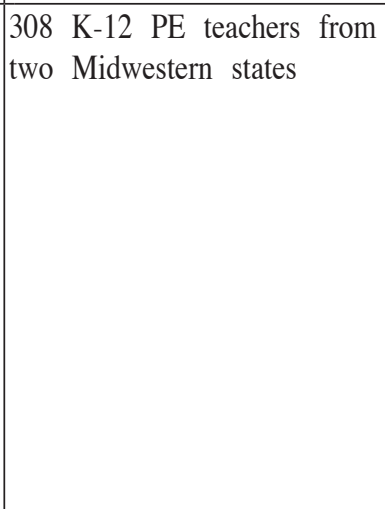 & $\begin{array}{l}\text { Teachers use teaching styles they } \\
\text { are familiar with not to benefit } \\
\text { the students } \\
\text { Teachers use large groups for } \\
\text { student participation } \\
\text { Dodgeball and elimination tag are } \\
\text { appropriate to play in class } \\
\text { Games that keep students "busy, } \\
\text { happy, and good" }\end{array}$ \\
\hline $\begin{array}{l}\text { Barney \& Pleban } \\
(2010)\end{array}$ & $\begin{array}{l}\text { To investigate parent's } \\
\text { knowledge of AIP in their } \\
\text { child's PE classes }\end{array}$ & $\begin{array}{l}311 \text { parents with a child } \\
\text { enrolled in elementary } \\
\text { school in the Midwest }\end{array}$ & $\begin{array}{l}\text { Fitness tests should administered } \\
\text { to identify students to receive an } \\
\text { award } \\
\text { Students should receive a grade } \\
\text { for dress, attendance and effort } \\
\text { Dodge ball and elimination tag } \\
\text { games are appropriate } \\
\text { Full-sided or large-sided games } \\
\text { are appropriate }\end{array}$ \\
\hline $\begin{array}{l}\text { Senne \& Strand } \\
(2009)\end{array}$ & $\begin{array}{l}\text { PETE students knowledge } \\
\text { and perceptions of their } \\
\text { K-12 PE teachers teaching } \\
\text { strategies dealing with AIP }\end{array}$ & $\begin{array}{l}258 \text { PETE majors from } \\
\text { five } \text { Midwestern universities }\end{array}$ & $\begin{array}{l}\text { PE Teachers teaching styles should } \\
\text { be familiar with the teacher not } \\
\text { the students } \\
\text { Dodgeball is appropriate } \\
\text { Elementary PE should have students } \\
\text { "busy, happy and good" }\end{array}$ \\
\hline $\begin{array}{l}\text { Barney \& Strand } \\
(2008)\end{array}$ & $\begin{array}{l}\text { To investigate high school } \\
\text { students knowledge of AIP } \\
\text { in high school PE }\end{array}$ & $\begin{array}{l}369 \text { high school students } \\
\text { from the upper Midwest }\end{array}$ & $\begin{array}{l}\text { Students should participate in mass } \\
\text { exercise with a class leader for } \\
\text { the purpose of a students fitness } \\
\text { Captains pick teams in front of } \\
\text { the whole class } \\
\text { Out of class assignments are } \\
\text { inappropriate } \\
\text { Student grades are determined by } \\
\text { dress and attendance to class }\end{array}$ \\
\hline
\end{tabular}




\begin{tabular}{|l|l|l|l|}
\hline $\begin{array}{l}\text { Strand, Barney \& DeFries- } \\
\text { Evans } \\
(2008)\end{array}$ & $\begin{array}{l}\text { Compare various populations } \\
\text { knowledge regarding AIP: } \\
\text { a) elementary ed. majors, } \\
\text { b) PETE majors, c) college } \\
\text { students }\end{array}$ & $\begin{array}{l}99 \text { PETE majors, 138 } \\
\text { elementary ed. majors, } 360 \\
\text { college students }\end{array}$ & $\begin{array}{l}\text { Elementary ed. Majors correctly } \\
\text { answered a higher majority of } \\
\text { survey statements then PETE } \\
\text { majors and college students }\end{array}$ \\
\hline $\begin{array}{l}\text { Barney \& Prusak } \\
\text { (In press) }\end{array}$ & $\begin{array}{l}\text { To investigate school } \\
\text { administrators (k-12) } \\
\text { knowledge of AIP }\end{array}$ & $\begin{array}{l}130 \text { school administrators } \\
\text { from two states }\end{array}$ & $\begin{array}{l}\text { Attendance and effort should be } \\
\text { graded } \\
\text { Large group militaristic calisthenics } \\
\text { are appropriate } \\
\text { Students getting awards for } \\
\text { participating in fitness testing } \\
\text { odge ball and elimination tag is } \\
\text { appropriate } \\
\text { Full-sided or large-sided games are } \\
\text { appropriate }\end{array}$ \\
\hline
\end{tabular}

\section{Repeat Offenders}

From the above-mentioned studies, it should be noted that participants within each group correctly identified a majority (80\%) of the AIP questionnaire statements as appropriate or inappropriate over the previously mentioned studies. However, it was found that eight survey statements were repeatedly incorrectly identified. These eight instructional practices are being labeled as 'repeat offenders'. What follows is a discussion of the repeat offender statements.

\section{The curriculum should consist of large group \& competitive team games.}

For this statement, a majority of participants (85\%) in each of five groups (PETE majors; middle grade students, parents, school administrators and K-12 PE teachers) incorrectly identified it as an appropriate instructional practice. When physical educators implement this practice they are inviting off-task student behaviors during the activity. As large groups and competitive team games are played in class, students tend to get bored with not being involved in the activity, thus having a negative effect on the students' learning. Physical educators can address these concerns by shortening or widening the playing space, using a bigger ball, changing game rules and by having students focus on certain skills within the context of multiple small-sided games (Barney \& Pleban, 2010; Prusak \& Barney, 2014).
2. Teachers should administer physical fitness tests once or twice each year for the purpose of identifying students to receive awards that meet a requirement of the school district or state department.

A majority of participants (70\%) in four groups (PETE majors, parents, elementary-aged students and school administrators) incorrectly identified this statement as being an appropriate instructional practice. This might suggest that these groups believe that students should receive some type of recognition for reaching some level of physical fitness. The form of recognition might be a trophy, a certificate, or simply a ribbon.

One might argue that awards send the wrong message to students in that the students who do not receive an award may be turned off to physical activity. Obviously, this has the possibility of affecting the students' motivation to exercise later in life. Those students who receive recognition may be extrinsically motivated when it comes to being physically active. However, as students get older and do not receive awards or recognition for participation, they may lose interest in being physically active (Nicholls, 1984).

It is important that physical educators promote the process of testing rather than just the product, and those students should work to improve on their results from previous fitness tests. The process 
orientation allows teachers the flexibility to help and encourage students while making fitness testing a positive experience (Barney \& Pleban, 2010). Prusak's (2005) program practice sheets are a good example of the process orientation, allowing student flexibility in assessing student learning and at the same time encouraging students during the assessment process. The program practice sheets simultaneously provide skill building with repetitions and assessment within a learning process.

\section{Calisthenics/mass exercise should be the arena for fitness development.}

A majority of participants (75\%) in two groups (PETE majors and school administrators) incorrectly identified this statement as appropriate. When physical educators use mass exercise experience in their classes, they are promoting the "one size fits all" fitness and exercise concepts. Pangrazi and Beighle (2013) stated that every student is different and therefore, physical educators must create opportunities and activities that benefit all students. This also applies to students' fitness activities and goals. Through proper planning and preparation a physical educator can provide all students with fitness activities to help them reach their individual goals. (Barney \& Prusak, in press).

4. Grading students on dress, attendance and effort as part of a student's grade.

A majority of participants (85\%) in four groups (PETE majors, middle school students, parents, and school administrators) incorrectly identified this instructional practice as approprite. For many years students have passed their physical education class because they "showed up" to class. Grading students on dress, attendance, and effort as a part the of a student's grade points to a mindset that has been established by many (Barney \& Prusak, in press).

Miller (2002) stated that basing grades on dress, attendance, and effort undermines physical education and the true purpose of a physical education class. The purpose of assessment is to access student learning. These categories of assessment are certainly not relevant assessments of students' affective skills related to physical education. Effort is a subjective measure and difficult for teachers to assess. In fact, a teacher might interpret one student's effort as casual or lackadaisical, but in the students' mind he/she is giving his/her best effort in the activity, thus creating problems with a student's assessment. Because effort is such a subjective assessment, parents and administrators may call into question the validity of the student's grade. If this practice of subjective assessment continues, physical educators will continue to demonstrate to parents and administrators that physical education is a glorified playtime during the school day. Teachers must explore a variety of alternative assessment techniques to analyze a student's understanding of his/her learning in physical education class (Barney \& Strand, 2006).

\section{Having captains pick teams in front of the} whole class.

This statement is probably one of the most commonly experienced inappropriate instructional practices with the groups that were studied. A majority of participants in five groups (middle grade students, high school students, parents, PETE majors, and elementary-aged students) incorrectly identified this statement as appropriate.

The practice of picking teams has caused many students in physical education classes to experience feelings of humiliation, embarrassment, and emotional scarring, has been painful, and damaging to those students who experienced being picked in front of classmates (Williams, 1996). Of the five groups that were studied, three of the groups that found picking teams to be an acceptable instructional practice were the students themselves. It could be concluded that they have been exposed to this practice since such a young age and that it is done frequently. Barney and Strand (2008) found that those students who were captains or those students who were picked first saw nothing wrong with this practice; however, those students who are picked last or toward the end may experience embarrassment or feelings of inferiority.

\section{Outside Class Assignments are not good.}

A majority of participants $(65 \%)$ in only three groups incorrectly identified this instructional practice, and not surprisingly it was middle grade students, high school students, and K-12 physical education teachers who agreed with the statement. There 
has been a culture that physical educators have not taken advantage of giving homework to their students (Barney, 2010). Simply put, the mindset is that homework is not assigned in physical education class.

With this said, there is a great opportunity for physical educators to implement homework. Giving students homework or outside-of-class assignments presents an opportunity for students to be active and learn while in activity. For example, a teacher can distribute pedometers and assign students to go on a walk with a family member or take the dog for a walk and then have the student report on how far they walked, what they saw, or whom they saw while on their walk (Pangrazi \& Beighle, 2013; Strand \& Bender, 2011).

\section{Dodge ball is good to play in PE.}

Dodge ball is an instructional practice that many students in physical education have been exposed to. For this statement, a majority of parents (84\%), PETE majors (67\%), middle grade students $(64 \%)$ elementary-aged students (87\%), school administrators (75\%), and k-12 physical education teachers (72\%) incorrectly identified this game as appropriate.

For many people dodge ball was probably the one activity or game that stands out in their mind regarding their physical education experience (Barney \& Pleban, 2010). Dodge ball has been in the media in all forms. Movies have glamorized dodge ball (Cooper, Dobkins \& Gillespie, 2007) while printed media has defended dodge ball in physical education class as a right of passage for young men (Reilly, 2001). Whether dodge ball is considered a positive or negative experience, it is an experience that many people remember from physical education.

The National Association for Sport and Physical Education (NASPE) (2006) position statement on dodge ball states, "dodge ball is not an appropriate activity for K-12 school physical education programs." The statement continues, "In quality physical education class teachers involve all children in activities. Students who are eliminated first in dodge ball are typically the ones who most need to be active and practice skills. Many times these students are also the ones with the least amount of confidence in their physical abilities" (p. 2). Being targeted because they are the "weaker" players, and being hit by a hard-thrown ball, does not help children develop skills such as running, dodging, throwing and catching. As always, physical educators must ask themselves, "What is best for the students?" If physical educators are honest with themselves, they will know that dodge ball is not appropriate and not in the students' best interest (Barney \& Christenson, 2014).

8. Assessing items that should focus on isolated skills in an artificial context, such as dribbling a basketball through cones.

A majority of participants in two groups (PETE majors and elementary-aged students) incorrectly identified this statement as appropriate. A goal of physical educators should be to teach skills that students are able to use their entire lives. One method of supporting this idea is to put students in game-like or authentic situations. When was the last time a favorite basketball player dribbled through cones during a game? It doesn't happen. The same applies for assessing students. The assessment needs to be in a game-like or in a authentic setting.

Graham, Holt-Hale and Parker (2004) said that assessment should be meaningful and worthwhile. Authentic or alternative assessments have become popular methods for evaluating student learning and include rubrics, peer observations, student journals, and checklists. Such assessments are also a more efficient use of time since they can be conducted as all students are active or can be completed among and between the students themselves (Barney \& Strand, 2006; Prusak, 2005).

\section{Why is knowing and understanding AIP so important?}

This section will discuss the impact and benefits AIP can have for each of the groups in the research studies (see Table 1).

\section{PETE Majors \& Faculty}

With the possibility of PETE majors teaching their physical education classes in the same manner they were taught in k-12 settings (Doolittle, et al., 1983), 
PETE faculties have a tremendous responsibility in the preparation of their PETE majors.

Many PETE majors have been exposed to a number of inappropriate instructional practices in physical education as students. There is the possibility these PETE majors have been exposed to inappropriate instructional practices for roughly 12 years of their K12 educational experience. When these PETE majors begin their teacher education classes, PETE faculties have 18 months to two years to retrain, or in some cases reprogram them (the students) to think and implement AIP in the classes they will be teaching.

Failure to implement AIP in lessons, activities, and games, may negatively impact student's attitudes towards physical education and physical activity. What benefits result when students have to stand around during class while captains pick teams, or from putting students in large groups to play a game or activity with one ball? Importantly, when PETE majors fail to implement AIP in physical education, it is looked upon as an inferior academic component to a student's education (Barney \& Christenson, 2013). Physical education has the potential to educate the whole student in the three domains: psychomotor, cognitive and affective. It is hoped that when students have a positive experience in physical education, the ramifications will be positive, throughout a person's lifetime.

\section{Parents}

One of the audiences that the AIP documents are directed to is a parent. Parents can be a very influential group when dealing with their child's education. Sheehy (2006) stated that parental dispositions towards education are immediate and of obvious importance. If physical education at all levels fails to meet the needs of students, the students' conversation with their parents and other teachers may get enough of a voice to eliminate physical education from the schools. Conversely, as AIP are being implemented in physical education classes, the child's experiences will filter back to the parents through their child, thus exposing parents to quality physical education. This will serve as a method of educating parents on the importance of physical education for their child and their education. As parents become more educated about AIP in physical education, it is hoped that they will support it in all possible ways, either by vote, financially, or verbally.
For many parent's, playing dodge ball, having captains pick teams in front of the whole class, and being graded on dressing out for class were all part of their physical education experience. And unfortunately, these experiences stand out in their memories as the activities that defined their physical education experience. Thus, they likely believe these activities are commonplace and expect that their children are participating in the same activities. Because of this, when physical educators implement AIP into their lessons, activities, and games, students then inform parents of what they are doing, and hopefully parent attitudes and perceptions are favorably transformed.

\section{Students in the Physical Education class}

Of all the groups that have been studied, the students in physical education classes are affected the most, both negatively and positively, by AIP. Strean (2009) studied negative experiences of adults when they were students in physical education classes. The following are statements adults made regarding their physical education experience. One adult stated, "it [PE] robbed me of the joy of physical activity for many years...it destroyed my physical confidence." Another stated, "To this day I feel totally inadequate... and have a natural reflex to avoid them [physical activites] at all costs... largely because of humiliating experiences in childhood."

Barney and Deutsch (2009) studied elementary classroom teacher's perceptions of elementary physical education. The researchers inquired if the elementary classroom teachers had a positive elementary physical education experience when they were children. The following are examples of both negative and positive experiences, "All I remember was running and dodge ball," "My teacher berated rather than encouraged, no variety of activities." Some of the positive statements were, "I'm 50 years old and Mr. Brown taught the joy and fun of exercise," "I loved PE and continue to stay active," and "I loved the games and having the opportunity to get out of my desk and move." These types of statements illustrate the impact both negatively and positively physical education class can have on a person's attitudes towards physical education class and being physically activity throughout life. 
The students in physical education classes really do not know what practices are appropriate or inappropriate, often until it is too late and negative outcomes have happened and attitudes established. Thus it is the physical educators responsibility to help students understand why practices are inappropriate or not in the students best interests (Barney, Strand \& Prusak, 2013). It is hoped that when physical educators implement AIP in their class activities, that positive attitudes will increase towards physical education class and physical activity, thus creating an attitude of being physically active throughout life (Barney \& Christenson, 2014). The effects of AIP can impact physical education as the students are in the class, but impact can and will be felt in the future. Aicinena (1991) succinctly stated that when students mature they will assume the role of voter, parent, school board member and politician, and will make important decisions that could affect the future of physical education.

\section{Final Thoughts}

The AIP research suggests that all of the studied groups have general knowledge of what are appropriate and inappropriate instructional practices in physical education classes. Yet, the results from the groups also show that many of the same instructional practices were repeatedly identified as appropriate when they were clearly inappropriate. The continued use and acceptance of the inappropriate instructional practices by teachers, students, and parents can seriously affect attitudes and desires to participate in physical activity. Along with affecting student attitudes, it also can affect a students' motivation. From previous research, student comments were such that when they participated in dodgeball and/ or having captains pick teams in front of the whole class that an ego-involved climate had been established. Once again, when physical educators implement AIP in their teaching, there is a greater chance of creating a task-involved class climate, with greater opportunities of students persisting in activity, exhibiting positive behavior and increased learning opportunities. Rather than pointing fingers and saying "It's your fault", the hope is that all who have a stake in a student's physical education experience will seriously consider what is the best for students in physical education class. The results from these studies only encourage continued work with appropriate instructional practices in physical education.

\section{Reference}

Ames, C. (1992). Motivation in sports and exercise. G. C. Roberts (Ed.). Champaign, IL. Human Kinetics.

Ames, C., \& Archer, J. (1988). Achievement goals in the classroom: Students learning strategies and motivation processes. Journal of Educational Psychology, 80, 260-267.

Aicinena, S. (1991). The teacher and student attitudes toward physical education. The Physical Educator, $48,28-32$.

Barney, D., \& Christenson, R. (2013). Do physical education majors know what instructional practices are appropriate in elementary physical education? The Global Journal of Health and Physical Education, 2, (1), 17-29.

Barney, D., \& Christenson, R. (2014). Elementary aged students perceptions regarding appropriate instructional practices in PE. The Physical Educator, 71, (1), 4158.

Barney, D., Christenson, R., \& Pleban, F. (2012). Preservice physical education teachers' knowledge of appropriate instructional practices in secondary school physical education. Journal of Teacher Education for Sustainability, 14, 30-38.

Barney, D., Christenson, R., \& Pleban, F. (in press). Physical education major's knowledge of appropriate instructional practices in middle school physical education. Asian Journal of Physical Education \& Recreation.

Barney, D., \& Deutsch. J. (2009). Elementary classroom teachers' attitudes and perspectives of elementary physical education. The Physical Educator, 66, (3), $12-20$.

Barney, D., \& Pleban, F. (2010). Parents knowledge of appropriate teaching practices in elementary school physical education programs. International Journal about Parents in Education, 4, (1), 1-10. 
Barney, D., \& Prusak, K. (in press) School Administrators knowledge of appropriate instructional practices in PE. Educational Administrators Quarterly.

Barney, D. \& Strand, B. (2006). Appropriate practices in elementary physical education: Creating a foundation for physical education majors. Teaching Elementary Physical Education, 17, (5), 20-23.

Barney, D. \& Strand, (2008). Do high school students know what practices are appropriate in physical education. The High School Journal, 92, (1), 33-40.

Barney, D., Strand, B., \& Prusak, K. (2013). Middle grade (6-9) students' knowledge of appropriate instructional practices in physical education. The Global Journal of Health and Physical Education Pedagogy, 2, 165-176.

Bryan, C.L. \& Solmon, M.A. (2007). Self-determination in physical education: Designing class environments to promote active lifestyles. Journal of Teaching in Physical Education, 26, (3), 260-278.

Burak, L.J., Rosenthal, M., \& Richardson, K. (2013). Examining attitudes, beliefs, and intentions regarding the use of exercise as punishment in physical education and sport: An Application of the theory of reasoned action. Journal of Applied Social Psychology, 43, 1436-1445.

Cooper, R.W., Dobkin, D. (Producers), \& Gillespie, C. (Director). (2007). Mr. Woodcock [Motion Picture]. United States of America: New Line Cinema.

Doolittle, S., Dodds, P., \& Placek, J. (1983). Persistence of beliefs about teaching during formal training of preservice teachers. Journal of Teaching in Physical Education, 12, 355-365.

Duda, J. L. (1996). Maximizing motivation in sport and physical education among children and adolescents: The case for greater task involvement. Quest, 48, 290-302.

Graham, G., Holt-Hale, S.A., \& Parker, M. (2004). Children moving. Boston, MA: McGraw-Hill.
Miller, D.K. (2002). Measurement by the physical educator: Why and how. Boston: McGraw-Hill.

National Association for Sport and Physical Education. (2006). Position on dodge ball in physical education [Position statement]. Reston, VA: Author.

National Association for Sport and Physical Education. (2009a). Appropriate instructional practice guidelines for elementary school physical education. Reston, VA: Author.

National Association for Sport and Physical Education. (2009b). Appropriate instructional practice guidelines for middle school physical education. Reston, VA: Author.

National Association for Sport and Physical Education. (2009c). Appropriate instructional practice guidelines for high school physical education. Reston, VA: Author.

Nicholls, J. (1984). Research on motivation in education: Student motivation vol. 1. New York: Academic Press.

Pangrazi, R., \& Beighle, A. (2013). Dynamic physical education for elementary school children $\left(17^{\text {th }}\right.$ ed.). San Francisco, CA: Pearson Benjamin Cummings.

Pantanowitz, M., Lidor, R., Nemet, D., \& Eliakim, A. (2011). The use of homework assignments in physical education among high school students. ICHER*SD Journal of Research, 6, 48-53.

Prusak, K.A. (2005). Motivating kids in the skill learning process. Teaching Elementary Physical Education, 16, (1), 11-17.

Prusak, K.A., \& Barney, D. (2014). Skill progression that maximize learning and motivation: Reflections for the classroom. Global Journal of Health and Physical Education Pedagogy, 3, (1), 69-80. 
Prusak, K.A., Treasure, D.C., \& McGee, G. (1998). Fostering higher levels of motivation, participation and achievement in middle school and jr. high school physical education. AZ AHPERD conference proceedings, Tucson, AZ.

Reilly, R. (2001. May). The weak shall inherit the gym. Sports Illustrated, 94, (20), 96.

Scantling,E., Strand, B., Lackey, D., \& McAleese, W. (1995). An analysis of physical education avoidance. The Physical Educator, 52, 197-202.

Senne, A., \& Strand, B. (2009). PETE students' knowledge of appropriate instructional strategies and perceived practice of their high school physical education teachers. Missouri Journal of Health, Physical Education, Recreation and Dance, 19, 2540.

Sheehy, D. (2006). Parent's perceptions of their child's $5^{\text {th }}$ grade physical education program. The Physical Educator, 63, 30-37.

Strand, B., Barney, D., \& DeFries-Evans, N. (2008). Knowledge of appropriate practices in elementary school physical education. The ICPHER*SD Journal of Research, 3, 24-30.

Strand, B., \& Bender, V. (2011). Knowledge and use of appropriate instructional strategies by physical education teachers. The Physical Educator, 68, (1), 2-17.

Strean, W.B. (2009). Remembering instructors: Play, pain and pedagogy. Qualitative Research in Sport and Exercise, 1, 210-220.

Williams, N.F. (1996). Inappropriate teaching practices. Journal of Physical Education, Recreation \& Dance, 67, (8), 45-49.

\section{Correspondence}

David Barney, Ed.D.

Associate Professor

Brigham Young University

249 G Smith Field House

Provo, Utah 84602

(801) 422-6477

(801) 422- 0930 FAX

David_Barney@byu.edu

Keven Prusak, Ph.D.

Associate Professor

Brigham Young University

249 H Smith Field House

Provo, Utah 84602

(801) 422-1560

Keven_Prusak@byu.edu

Brad Strand, Ph.D.

Professor

North Dakota State University

Health, Nutrition \& Exercise Science

NDSU Dept. \#6050

P.O. Box 6050

Fargo, North Dakota

58105-6050

(701) 231-9718

Bradford.Strand@ndsu.edu

Robert Christenson, Ed.D.

Associate Professor

Oklahoma State University

188 Colvin Center

Stillwater, OK 74078

(405) 744-5502

Robert.christenson@okstate.edu 